\title{
Style Moderne and the Rediscovery \\ of the Wooden Architecture \\ of the Russian North: \\ the Photographic Connection
}

\author{
William C. Brumfield* \\ Tulane University \\ New Orleans, Louisiana, USA
}

Received 17.06.2016, received in revised form 20.07.2016, accepted 14.09.2016

\begin{abstract}
The pre-Petrine "backwardness" of Russia's wooden architecture would become a point of interest in the nineteenth century, as Russian intellectuals and artists began to search for origins, antecedents and authenticity in the native culture. Engravings of traditional structures began to be widely distributed and published. Among the first artists to define the wooden vernacular as a stylistic inspiration were Viktor Hartmann and Ivan Ropet, both of whom worked at Abramtsevo in the early 1870s. Other Abramtsevo artists - Vasilii Polenov, Viktor Vasnetsov, Konstantin Korovin, and to some extent Aleksandr Golovin - introduced their painterly conception of mass and space into architectonic form. The prominence of the crafts revival and the use of folk motifs demonstrate a confluence of purpose and understanding among a group of artists, set designers, and architects at the turn of the century. The logical bond between material and structure in the medieval or folk traditions of pre-Petrine Russian architecture was given an aesthetic interpretation in the neo-Russian variant of the style moderne, which spread in the early twentieth century throughout Russia. The work of Sergei Maliutin is particularly significant in this area. The article proposes that photography at the turn of the 20th century played a crucial role in presenting forms of traditional wooden architecture to the Russian public and to architects themselves. Of particular importance was the publication of Igor' Grabar's multi-volume History of Russian Art, the first part of which was dedicated to pre-Petrine architecture, including the wooden churches of the North in photographs by artists such as Ivan Bilibin. The article concludes with a discussion of the work of Fedor Shekhtel as seen in the context of photographs of traditional wooden architecture.
\end{abstract}

Keywords: Wooden architecture, Abramtsevo, Viktor Hartmann, Ivan Ropet, Vasilii Polenov, Viktor Vasnetsov, Konstantin Korovin, Sergei Maliutin, Talashkino, style moderne, neo-Russian style, Sergei Diagilev, Igor Grabar, Ivan Bilibin, Fedor Shekhtel, international expositions.

DOI: 10.17516/1997-1370-2016-9-10-2383-2397.

Research area: art history.

(C) Siberian Federal University. All rights reserved

* Corresponding author E-mail address: william.brumfield@gmail.com 
For much of Russia's history the built environment was overwhelmingly defined by wooden structures, occasionally punctuated by a masonry church or the brick walls of a monastery. Even the dwellings of the rich and powerful were usually log structures, including the great palace at Kolomenskoe, built during the reign of Aleksei Mikhailovich and demolished in the eighteenth century by order of Catherine the Great.

With the rapid assimilation of western styles of building during the reign of Peter the Great, wooden architecture was increasingly relegated to the background. Wooden structures remained an indispensible but anonymous part of Russian life, an unacknowledged milieu whose anonymity was a reflection of its status as something backward, something that belonged to a period before the civilizing European enlightenment brought by Peter the Great. Russia's major cities - above all St. Petersburg and Moscow - were increasingly, inexorably dominated by masonry buildings for palaces, churches, administrative and commercial buildings, as well as apartment buildings and private houses.

In the inevitable cyclical manner of style and history, the very pre-Petrine "backwardness" of Russia's wooden architecture would become a point of interest in the nineteenth century, as Russian intellectual and artists began to search for origins, antecedents and authenticity in the native culture. Engravings of traditional structures began to be widely distributed and published. One of the early signals of this process of reaffirmation can be found in the "izba" (Fig. 1) designed by Nikolai Nikitin for the noted historian and Moscow University professor Mikhail Pogodin ${ }^{1}$. The use of an clearly traditionalist style for the house of such a prominent intellectual was intended to elevate the anonymous quality of vernacular architecture to the virtue of national authenticity. Other such houses followed as a reflection of the owners' allegiance to various national -

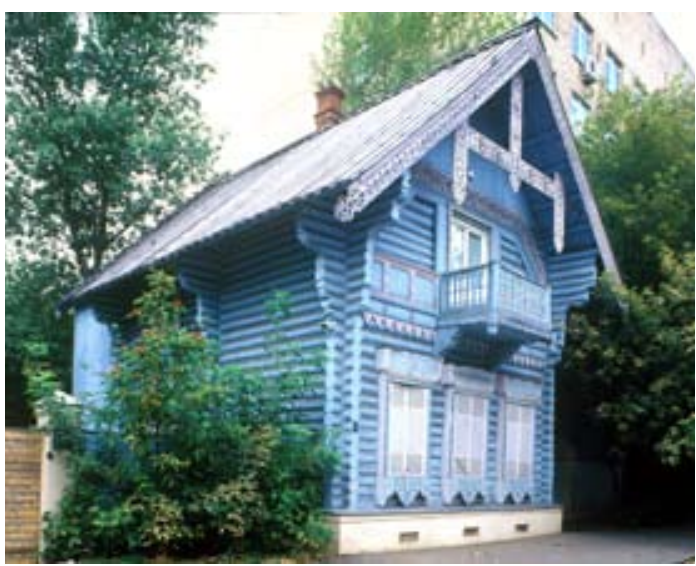

Fig. 1. Moscow. Pogodin “izba”. Photo: William Brumfield (26/8/2007)

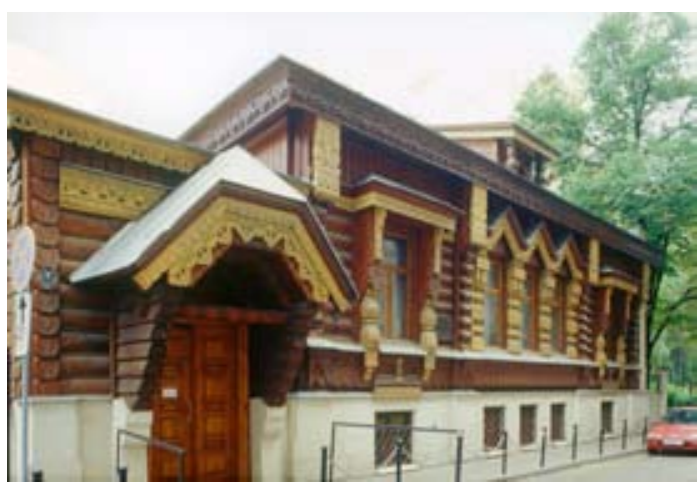

Fig. 2. Moscow. AleksandrPorokhovshchikov house. Photo: William Brumfield (26/8/2007)

or Pan-Slavic - programs. Architects such as Andrei Huhn (Porokhovshchikov house, Fig. 2), Nikolai Pozdeev, and Viktor Vasnetsov began to adapt the asymmetrical and three-dimensional characteristics of old Russian architecture to their work in both wood and brick ${ }^{2}$. Vasnetsov's own house-studio is an excellent example of this adaptation, with its log teremok (1892-94)

The most directly aesthetic, stylistic interpretation of the wooden vernacular, however, appeared in the 1870s. It was above all associated with the estate of Abramtsevo, purchased by Savva Mamontov the year after the death of his father, whose considerable fortune he inherited and enlarged as one of Russia's most energetic railway developers. Mamontov's «colony» at 
Abramtsevo provides a quintessential example of the productive relation between entrepreneur and artist in the post-reform period ${ }^{3}$. Although Abramtsevo would soon be rivaled by another center of vernacular revivalism at the Talashkino estate of Princess Maria Tenisheva, Mamontov's Abramtsevo group was unique in its breadth of artistic interests and its influence on architecture and design at the turn of the century.

Among the first artists to define the wooden vernacular as a stylistic inspiration were Viktor Hartmann and Ivan Ropet, both of whom worked at the estate in the early 1870 s. Hartmann, shortly before his death in 1873 , built a ceramics studio at Abramtsevo, with richly carved wooden decorations typical of the crafts revival (Fig. 3-5). Ropet's teremok bathhouse there, more interesting structurally than Hartmann's work, united asymmetrical shapes under a steep trapezoidal roof that serves as a backdrop for the window and porch gables (Fig. 6-8). The fanciful manner of the teremok gave a foretaste of freestyle, sculpted architecture of the new style (style moderne) at the turn of the century. Many Russian artists would subsequently elaborate upon the teremok theme, in art, architecture, and stage design.

The architectural collaboration at Abramtsevo was not the last occasion when a painter associated with that circle made an original contribution to Russian architecture. In 1896 Konstantin Korovin, who had painted stage settings for Mamontov's opera productions, designed the Pavilion of the Far North at the 1896 All-Russian Arts and Industry Exhibition in Nizhni Novgorod. (Fig. 9) Though more modest than the large pavilions by Pomerantsev for the same exhibition, Korovin's innovative pavilion exemplified his understanding of structure derived from traditional (in this case wooden) forms. The pavilion has no trace of the ornate «folk» decoration usually associated with Russian wooden architecture in the nineteenth century,

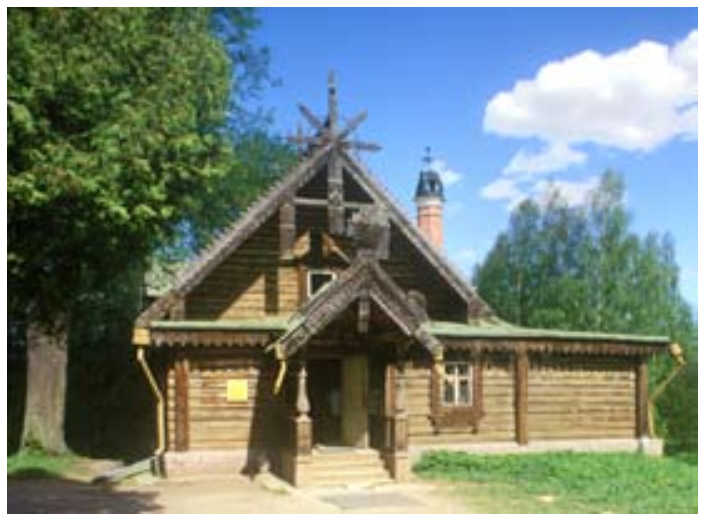

Fig. 3. Abramtsevo.Ceramics Workshop, main facade. Photo: William Brumfield (25/5/1999)

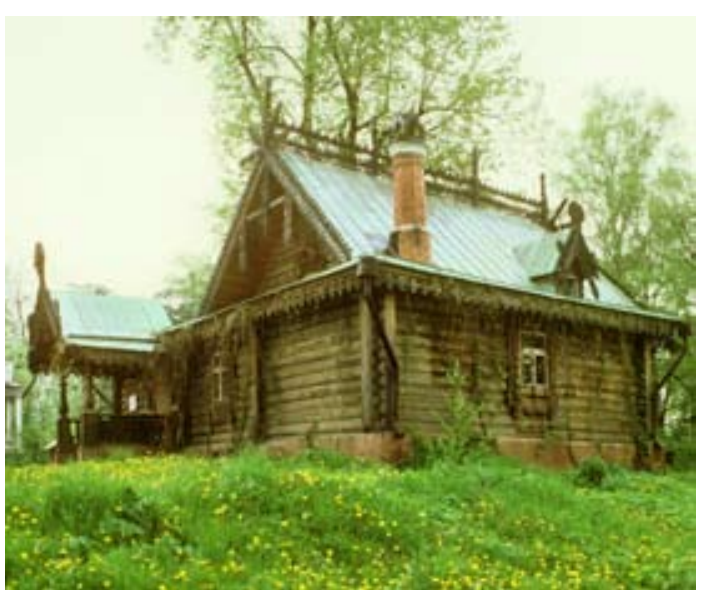

Fig. 4. Abramtsevo. Ceramics Workshop, southwest view. Photo: William Brumfield (18/5/1990)

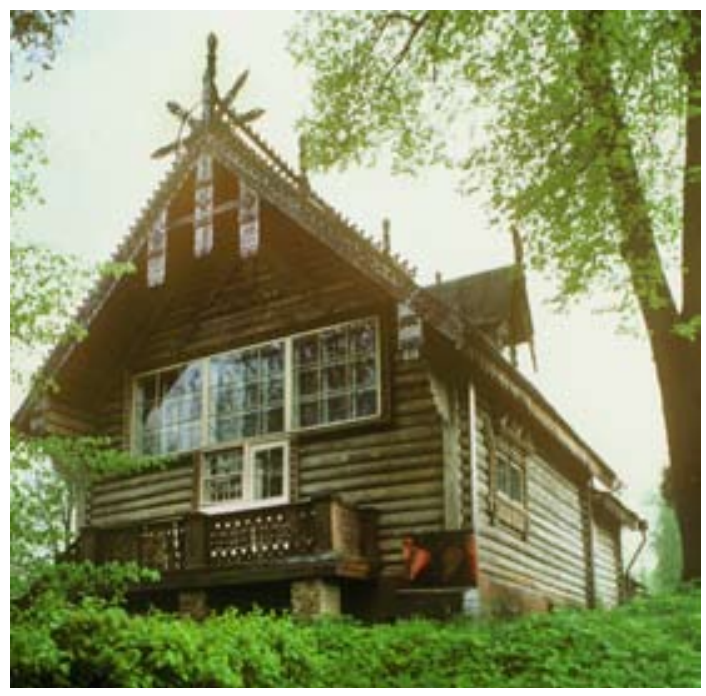

Fig. 5. Abramtsevo. Ceramics Workshop, studio facade. Photo: William Brumfield (18/5/1990) 


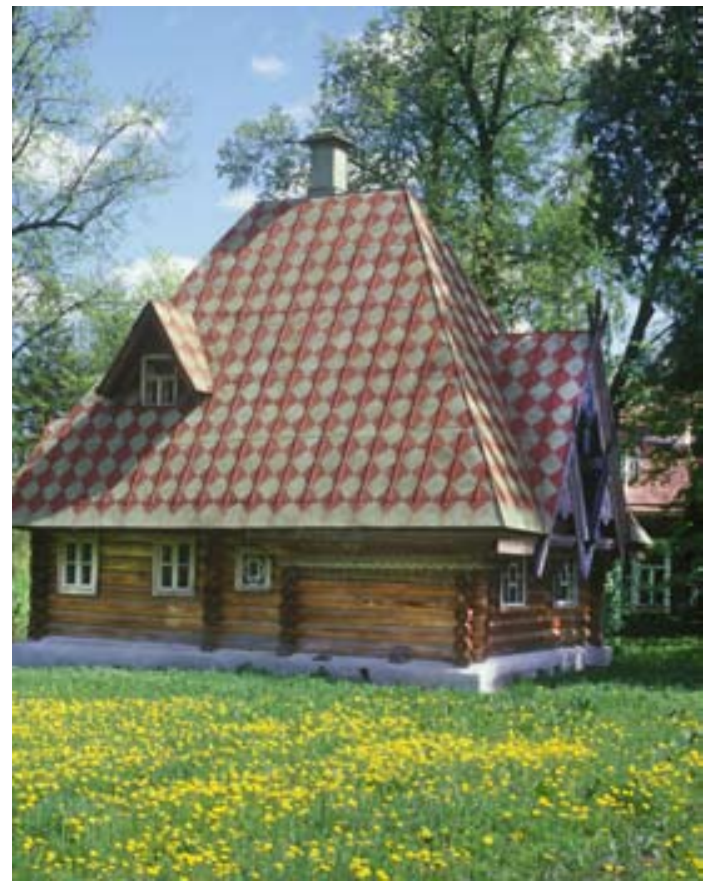

Fig. 6. Abramtsevo. Bathhouse (Teremok). Photo: William Brumfield (25/5/1999)

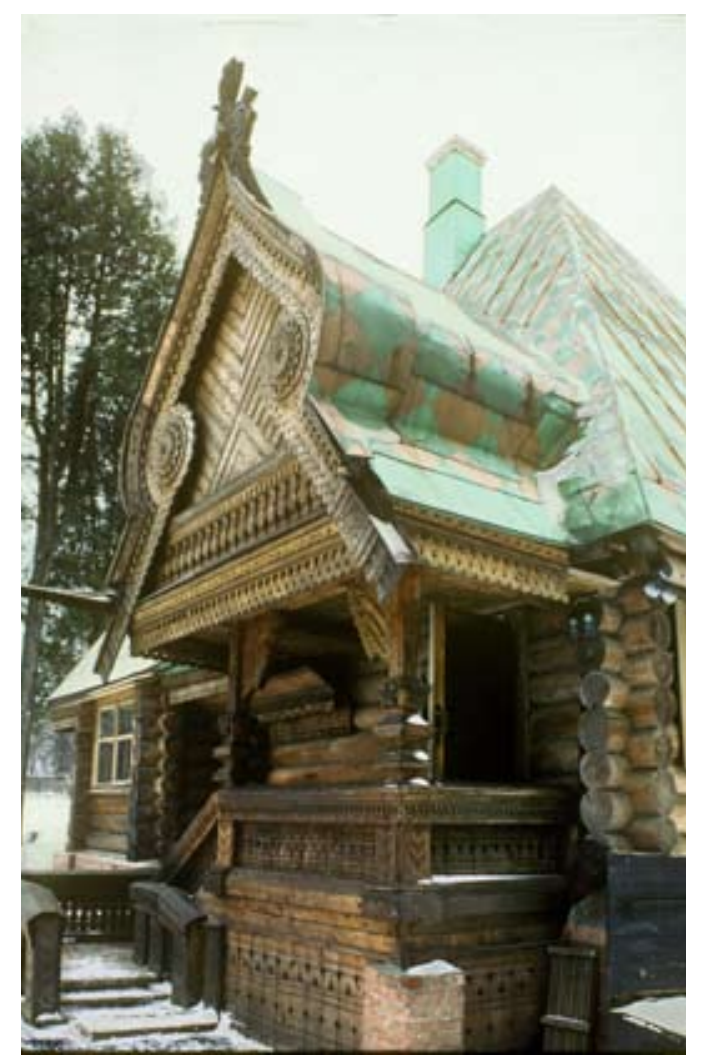

Fig. 8. Abramtsevo. Bathhouse (Teremok), entrance with decorative gable. Photo: William Brumfield (25/3/1984)

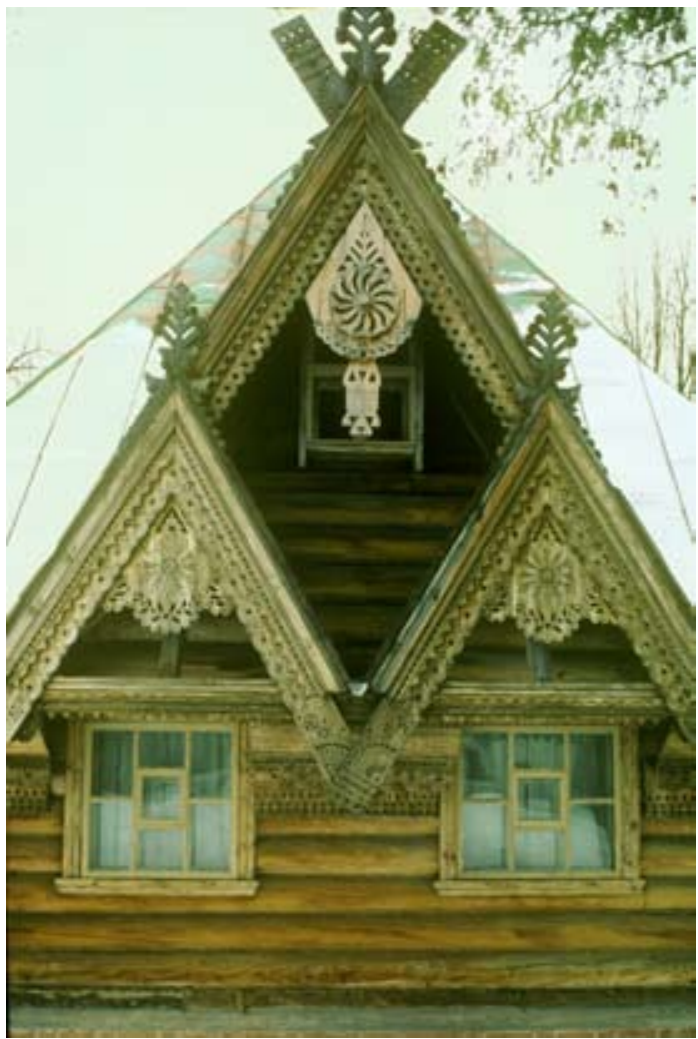

Fig. 7. Abramtsevo. Bathhouse (Teremok), decorative endboards. Photo: William Brumfield (25/3/1984)

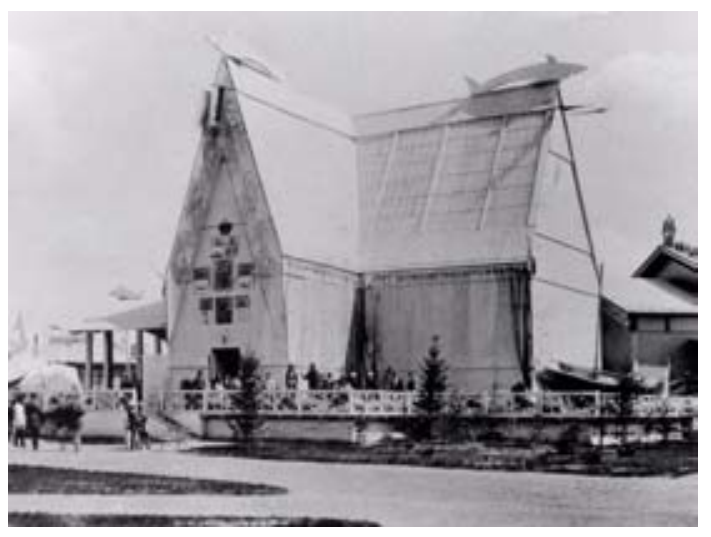

Fig. 9. Nizhnii Novgorod 1896 Exhibition. Pavilion of the Far North. From Vidy vserossiiskoi khudozhestvennoi promyshlennoi vystavki $1896 \mathrm{~g}$. v Nizhnem Novgorode 
instead, Korovin used his materials to create a clearly defined sculpted mass.

Although neither Korovin nor Vasnetsov used technologically advanced materials or construction methods, their approach to architectural form suggested a means to lessen the opposition between technology and historicism. Elena Borisova notes that in architecture the Abramtsevo painters «could satisfy that tendency to the plastic that professional architects felt somewhat later, for which painters still had not found a place on their canvases." ${ }^{\text {. }}$. Precisely at this juncture, ahead of the new styles in both painting and architecture, the Abramtsevo artists - Polenov, Viktor Vasnetsov, Korovin, and to some extent Aleksandr Golovin - introduced their painterly conception of mass and space into architectonic form. As Viktor Vasnetsov had demonstrated in his monumental Tretiakov Gallery entrance (1899-1901), traditional motifs could be used in a modern context.

By the beginning of the century, the brothers Viktor and Apollonarii Vasnetsov, as well as Aleksandr Golovin and Maliutin had published or displayed (in some cases, built) variants on the teremok. No one explored the possibilities of the teremok more dramatically than the artist Sergei Maliutin (1859-1937) who was invited to be the artist in residence at the arts and crafts community of Talashkino - the estate of the community's benefactor, Princess Maria Tenisheva. In 1901 Maliutin designed the teremok at Talashkino (Fig. 10-15), a log structure decorated with fanciful interpretations of Russian folk art and resembling the Russian pavilion designed by Konstantin Korovin and Aleksandr Golovin for the 1900 Paris Exposition. Sergei Diagilev was ecstatic in his praise of Maliutin's teremok at Talashkino, which he considered the expression of a genuinely national, non-Western architectural form. In Diagilev's view, Maliutin, together with the Finnish painter and designer

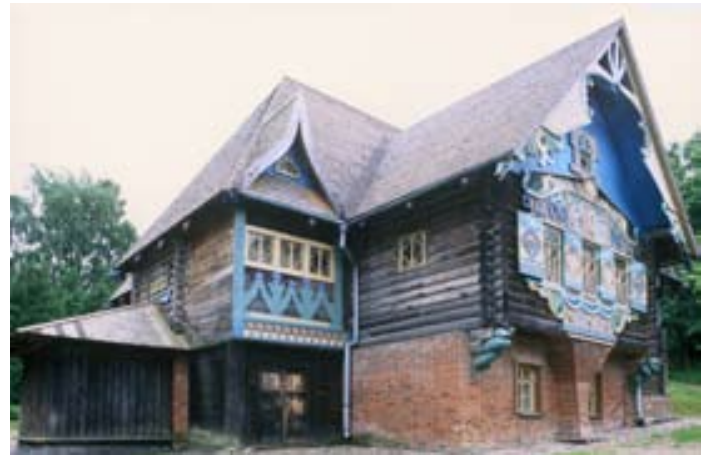

Fig. 10. Flenovo. Talashkino estate, Teremok, front and side facades. Photo: William Brumfield (16/7/2006)

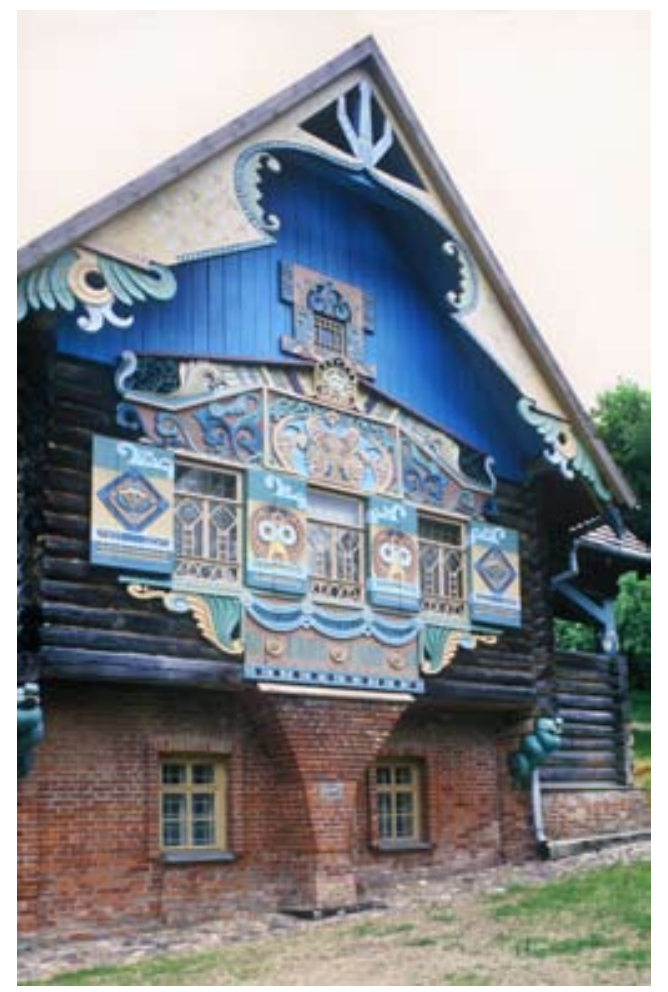

Fig. 11. Flenovo. Talashkino estate, Teremok decoration on side facade. Photo: William Brumfield (16/7/2006)

Gallen-Kalela, had established in the north of Europe the basis for a «second rinascimento would eventually lead to a «new aesthetic, a new Florence» ${ }^{5}$.

The prominence of the crafts revival and the use of folk motifs - however stagy demonstrate a remarkable confluence of purpose and understanding among a group of artists, set 


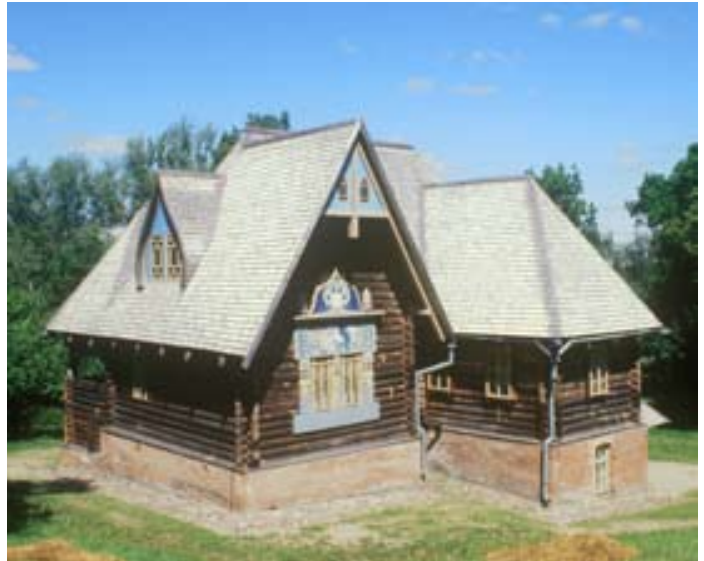

Fig. 12. Flenovo. Talashkino estate, Teremok, back facade. Photo: William Brumfield (17/7/2006)

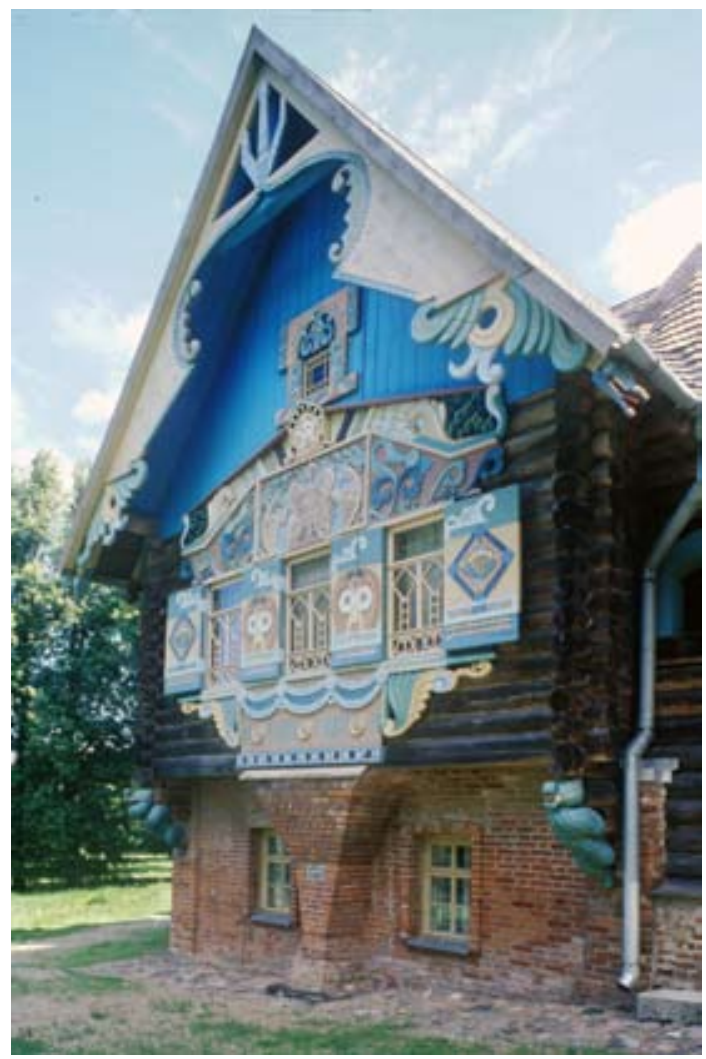

Fig. 14. Flenovo. Talashkino estate, Teremok, side facade. Photo: William Brumfield (17/7/2006)

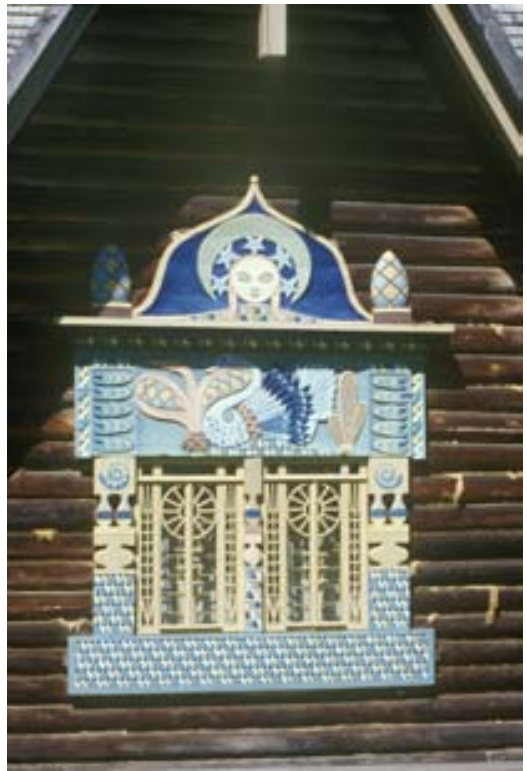

Fig. 13. Flenovo. Talashkino estate, Teremok, back facade, nalichnik. Photo: William Brumfield (17/7/2006)

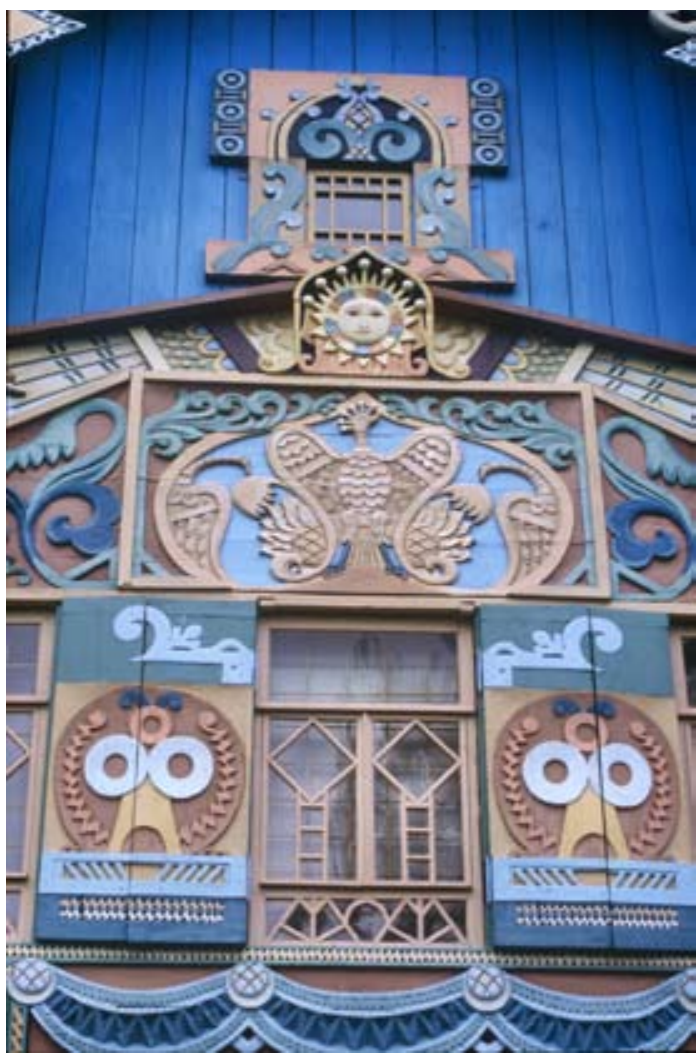

Fig. 15. Flenovo. Talashkino estate, Teremok, side facade, center with decorative elements. Photo: William Brumfield (16/7/2006) 


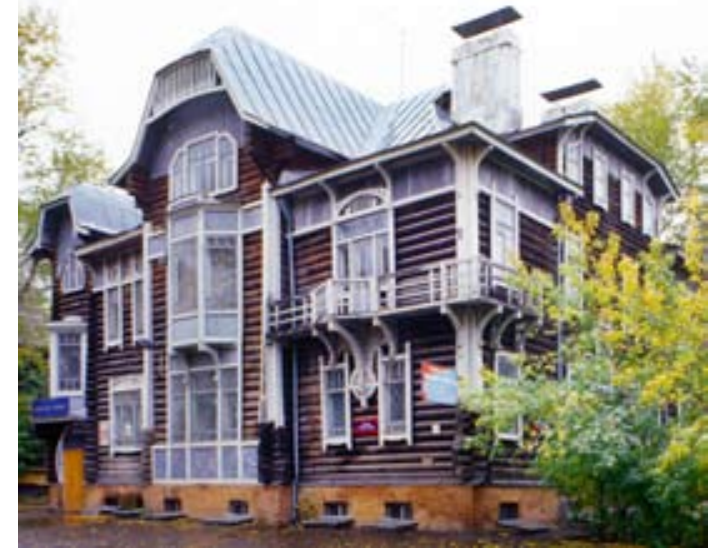

Fig. 16. Tomsk. A. D. Kriachkov house. Photo: William Brumfield (26/9/1999)

designers, and architects at the turn of the century. The Vasnetsov brothers as well as Golovin, Korovin, Vrubel, Maliutin, Shekhtel, Polenov, and others had each explored the connection between architecture and decorative art. The logical bond between material and structure in the medieval or folk traditions of pre-Petrine Russian architecture was given an aesthetic interpretation in the neoRussian variant of the style moderne, which spread in the early twentieth century throughout Russia. Indeed, some of the best-preserved examples are in Siberia, as exemplified by the style moderne wooden mansion built in Tomsk by the architect Andrei Kriachkov. (Fig. 16)

As Grigorii Sternin notes in regard to the Russian decorative arts displayed at the Paris Exposition: «National exotica served here as a means of theatricalization, and spectacle proved to be one of the most important inner properties of the 'neo-Russian style.' The handicrafts from Talashkino demonstrated how completely the 'neo-Russian' style had been incorporated into the style moderne.» Sternin argues that although Golovin and Maliutin were dilettantes in their imitations of folk crafts, their purpose was to express the «magic» of folk creativity. "The deliberate conditionality [uslovnost] of the decorative image was the very basis on which the 'new style' affirmed itself $\rangle^{6}$.

Although the gap between stage set and rational architecture remained in this large apartment building, Maliutin continued to explore the idea of the teremok_as a union of theater, architecture, and interior design - all devoted to a revived awareness of Russian traditions. The most flamboyant example occurred in his design for the apartment house commissioned by the construction engineer Petr Nikolaevich Pertsov on Prechistenka Quay (Fig. 17-18). In his design for the Pertsov building (1905-07), Maliutin used ceramic panels and other ornamentation based on exaggerated, «conditional» representations of folk art. The staginess of Maliutin's sketch for the building - reproduced in the 1907 issue of the Annual of the Society of Architect-Artists-masked the basic structure with a panoply of steeplypitched roofs, towers, elaborately-decorated

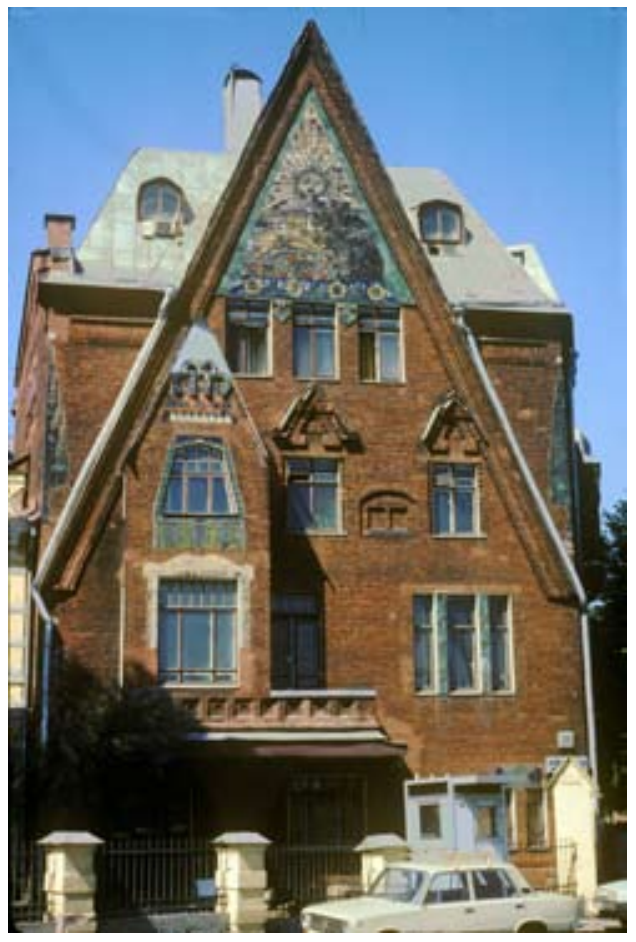

Fig. 17. Moscow. Pertsov apartment house, south facade. Photo: William Brumfield 


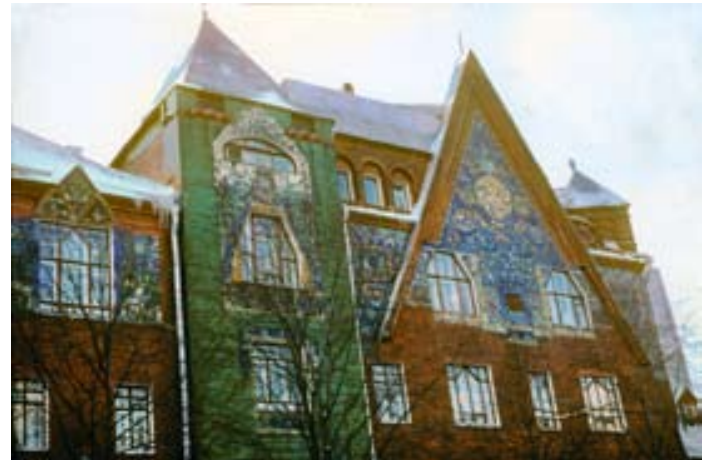

Fig. 18. Moscow. Pertsov apartment house, east facade. Photo: William Brumfield

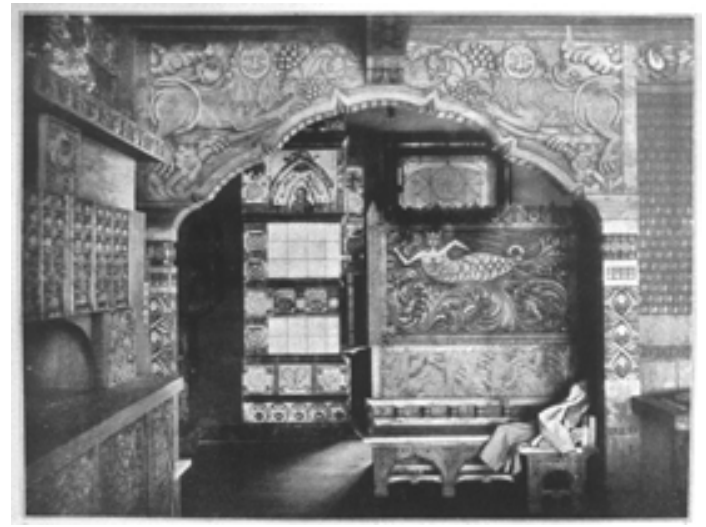

Fig. 19. Moscow. Pertsov apartment house, interior. Apartment designed by Sergei Maliutin for A. O. Pertsova. From Ezhegodnik Obshchestva arkhitektorov-khudozhnikov, 1908

balconies and window surrounds, large ceramic panels, as well as door and window openings of unusual configurations. Maliutin intended to reproduce the asymmetry of the medieval teremok, a word that includes the concepts of «tower» and «chambers»; but the ideal proved beyond reach, and Maliutin's original design was considerably modified by the architect who constructed the building, Nikolai Zhukov?

Written some five years before the completion of the Pertsov building, Igor Grabar's critical analysis of the application of Russian folk motifs in contemporary furniture design and the decorative arts seems particularly relevant to the interior of the Pertsov apartment (Fig. 19). Grabar was pleased with the success of the Russian pavilion - based on the arts and crafts revival - at the 1900 Paris Exposition, but he was concerned by the deliberate crudity with which Russian artists such as Golovin and Polenova incorporated folk art as part of modern design. Grabar acknowledged the aesthetic pleasures of genuine folk art, yet the excessive imitation, rather than creative reworking, of these motifs leads to a new form of cliche - and to furniture that is «hellishly uncomfortable.» In contemporary life, he noted, «one wants in everyday surroundings a measure of comfort, of calm, one wants to eat and rest in comfort, without having to face endless lines and colors crawling at you from the wall in front, like the glass of a kalaidescope ${ }^{8}$

The artist and photographer Ivan Bilibin, one of the most dedicated students of the traditional art and architecture of the Russian north, also criticized the modern «Russian style» for its superficiality and tendency toward a stereotyped representation of the past. His article «Narodnoe tvorchestvo severa» appeared in one of the 1904 issues of Mir iskusstva and was accompanied by seventy of Bilibin's photographs of folk handicrafts and wooden architecture - primarily churches in the traditional Russian north ${ }^{9}$. A magnificent example is the three-towered log Cathedral of the Dormition which still stands in the White Sea port town of Kem. (Fig. 20-21)

Bilibin's involvement in photography as an artistic and documentary medium is reflective of a general Russian fascination with photography at the latter part of the nineteenth century. A number of Russian professional photographers excelled in documenting the people and monuments of a vast land. At the beginning of the twentieth century photographers such as Sergei M. ProkudinGorskii were examining innovations in color photography and applying these techniques to recording the cultural variety of the Russian empire, from the north to the ancient cities of Central Asia ${ }^{10}$. 


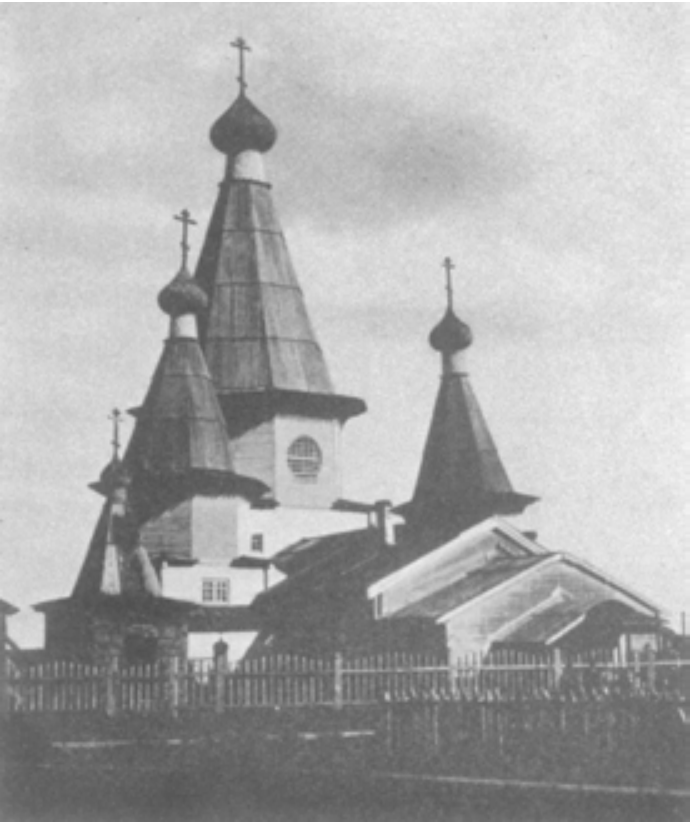

Fig. 20. Kem. Cathedral of the Dormition, northwest view.From Istoriiarusskogoiskusstva, vol. 1 (1910). Photo: Ivan Bilibin

A further stimulus to the application of photography in Russian art history - indeed, to the reaffirmation of Russian artistic culture - was the publication of Igor' Grabar's pioneering multivolumed History of Russian Art, the first part of which was dedicated to pre-Petrine architecture including the wooden churches of the North ${ }^{11}$. The volume's remarkable photographs, which included the work of Bilibin, are a valuable record of monuments that in many cases no longer exist, or exist in much modified form. In some cases the photographs reflect modifications in the nineteenth century, such as the addition of plank siding (obshivka) painted white. Although the Soviet school of architectural preservation considered this siding an unnecessary addition that hid the original mastery of northern builders, in some cases the siding emphasizes the plasticity of the structure and conveys a curiously "modern" character.

This sense of the "modern" in traditional structures is particularly evident, it seems to us,

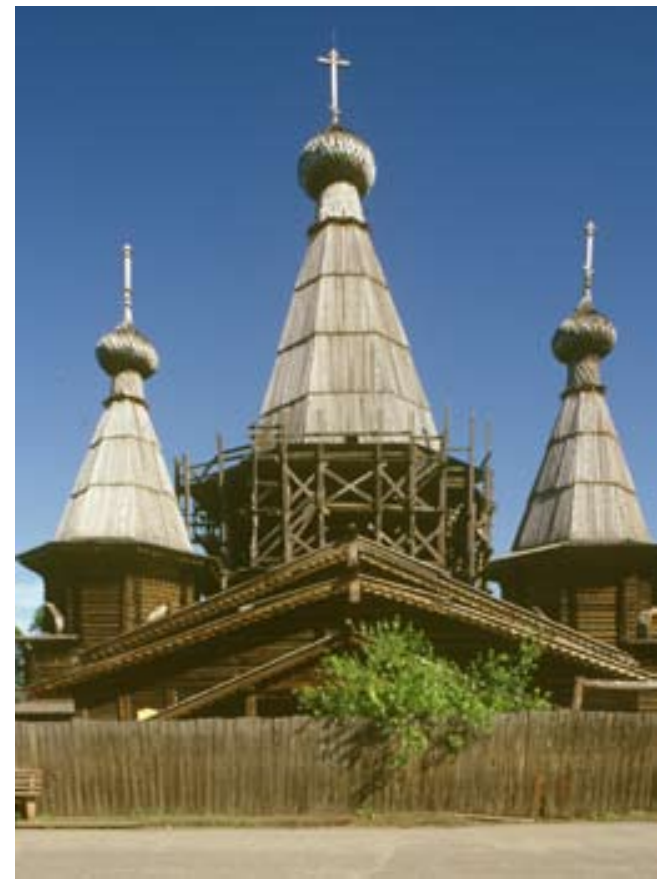

Fig. 21. Kem. Cathedral of the Dormition, northwest view. Photo: William Brumfield (25/7/2001)

in V. A. Plotnikov's photograph of the Dormition Church at Varzuga (Fig. 22); in the first volume of History of Russian Art). The ancient village of Varzuga, located on the river of the same name which flows into the White Sea at the southeastern part of the Kola Peninsula. Varzuga has one of the most dramatic architectural landmarks in the north: the Church of the Dormition of the Mother of God, built of pine logs in $1674^{12}$. The soaring structure, which rises 34 meters above the steep right bank of the Varzuga River, culminates in a tall "tent" eight-sided roof.

Notable for its construction logic as well as its beauty, the basic log structure from 1674 has withstood the natural elements in its exposed location. A number of modifications were made in the $19^{\text {th }}$ century, and both exterior and interior were clad in plank siding at the end of the century. A restoration completed in 1973 returned the upper part of the church to what is presumed to be its earlier appearance (Fig. 23-25). However, in Plotnikov's photograph the white-clad design 


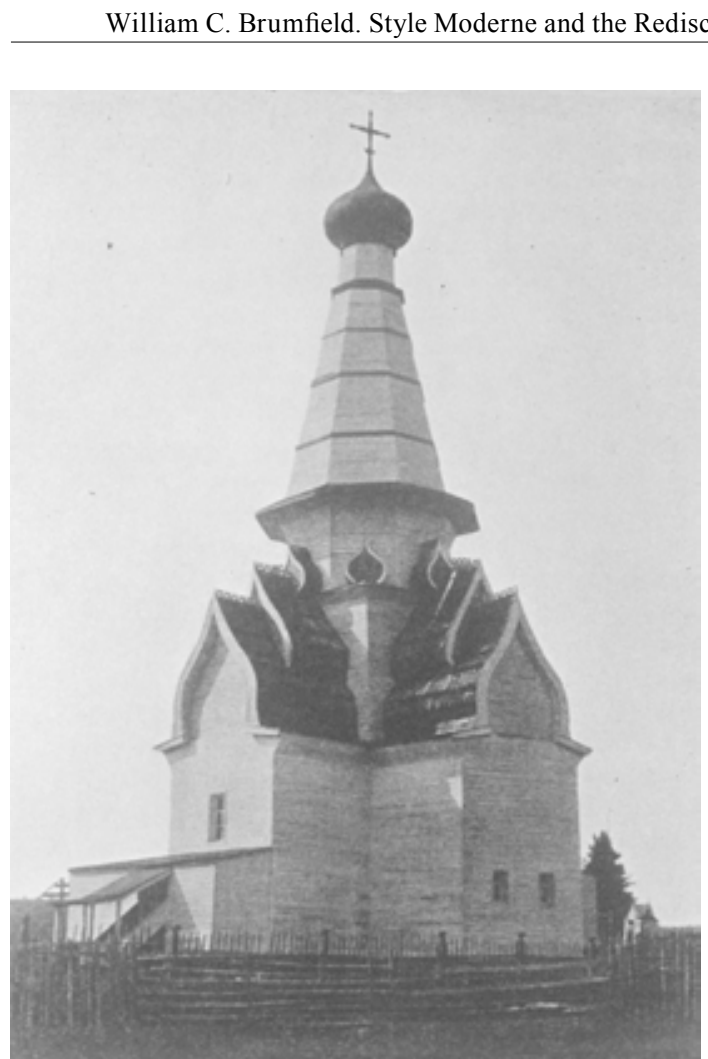

Fig. 22. Varzuga. Church of the Dormition.From Istoriiarusskogoiskusstva, vol. 1 (1910). Photo: V. A. Plotnikov

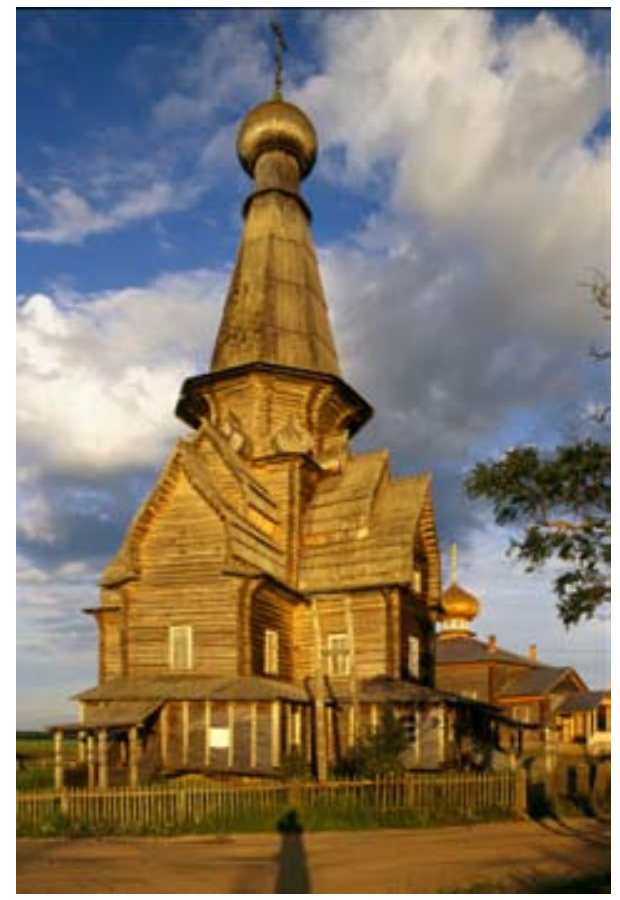

Fig. 24. Varzuga. Church of the Dormition, northwest view. Photo: William Brumfield (21/7/2001)

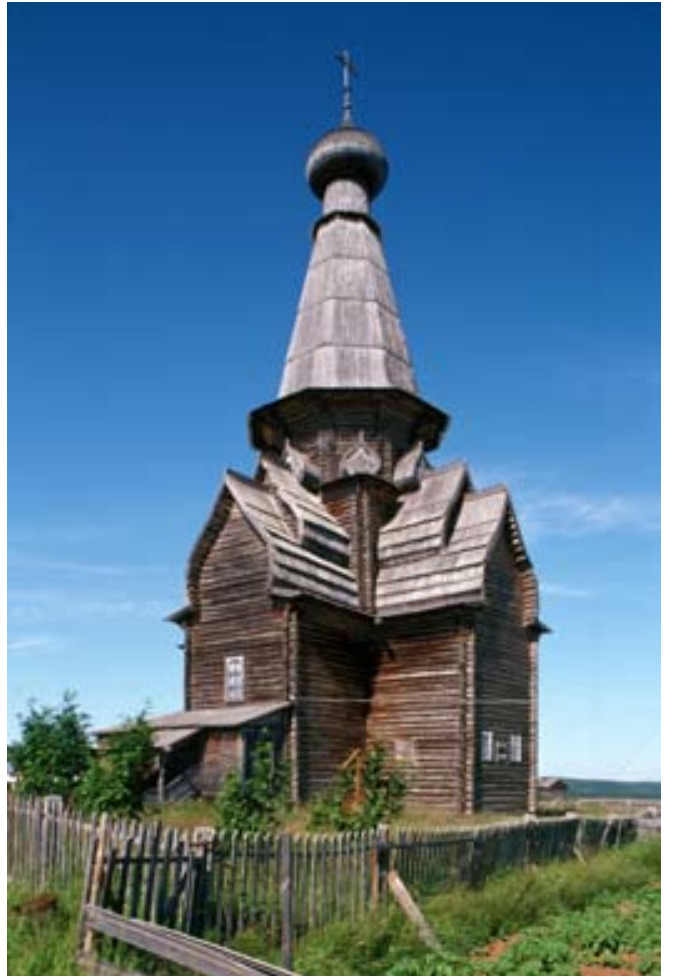

Fig. 23. Varzuga. Church of the Dormition, southeast view. Photo: William Brumfield (21/7/2001)

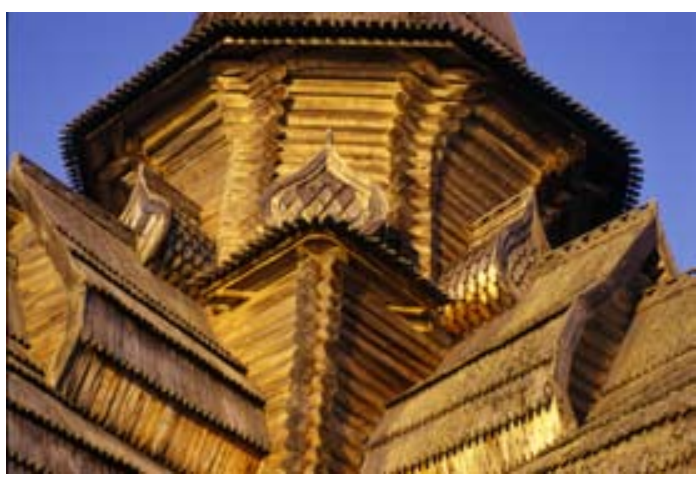

Fig. 25. Varzuga. Church of the Dormition, upper tier, northwest corner. Photo: William Brumfield (20/7/2001)

of the Dormition Church seems almost futuristic in its soaring, clean contours, punctuated with curved bochka motifs.

It is reasonable to assume that the early volumes of the Grabar History of Russian Art were known to the most accomplished and versatile 
architect of Russia's style moderne, Fedor Shekhtel. Here he would have seen photographs of traditional Russian architecture of the Russian north with its striking tectonic logic. A similar logic appeared in some of the best examples of his own work at the beginning of the twentieth century. Even before the publication of the first volume of History of Russian Art, Shekhtel had integrated techniques of wooden architecture into one of his largest projects, a project that interpreted traditional forms in a coherent aesthetic expressive of both function and the decorative arts.

When the Russian government commissioned him to create a series of pavilions for the 1901 Glasgow International Exhibition, Shekhtel decided to use vernacular wooden architecture as the natural conceptual basis for the central pavilion as well as for the buildings that housed exhibits on mining, forestry, and agriculture. The exhibition was intended to market Russian products in Great Britain, and the Ministry of Finance displayed sound aesthetic judgment in generously supporting the designs of an architect of «advanced» views. In contrast to the eclectic structures elsewhere at the exhibition, the Russian pavilions created a strong impression with their bold silhouettes and polychromatic decoration ${ }^{13}$.

At Glasgow, the ministry provided Shekhtel with 30,000 rubles in construction funds and a skilled labor force of 210 peasant carpenters, supplemented by the six graduates of Moscow's prestigious Stroganov School of Technical Design who carried out Shekhtel's design for the ornamental painting ${ }^{14}$. The carpenters provide the key to the architect's intention: a modernized interpretation of native wooden structures, which are among the most ingenious forms of Russian architecture. By returning to the organic building material par excellence, Shekhtel continued the work of Hartman in the massive wooden structures for the 1872 Polytechnical Exhibit and Ropet in the designs at Abramtsevo.

Shekhtel had already designed a wooden theater for Sokolniki Park in Moscow, but it was austerely functional, unlike the picturesque Glasgow pavilions, which were based in part on wooden churches of the far north but in other respects the product of Shekhtel's imagination. Around the central pavilion - the building closest to the traditional prototypes with its pyramidal silhouette and large tent roof (Fig. 26) - the rest of the Russian buildings were grouped. Having stated the central motif of the Russian «village,» Shekhtel freely interpreted the wooden structures of the other pavilions, with references to folk or traditional elements in both construction and decoration.

The modernity of this interpretation appeared most striking in the agriculture pavilion;

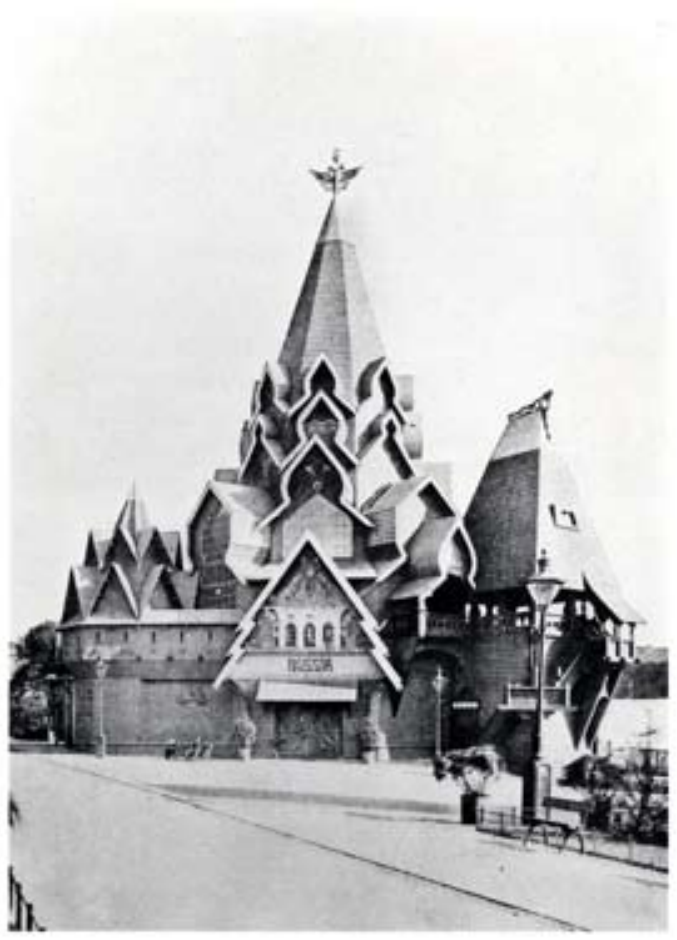

Fig. 26. Glasgow. Central Pavilion, Russian section, 1901 Glasgow Exhibition. From Ezhegodnik Moskovskogo arkhitekturnogo obshchestva, 1909 


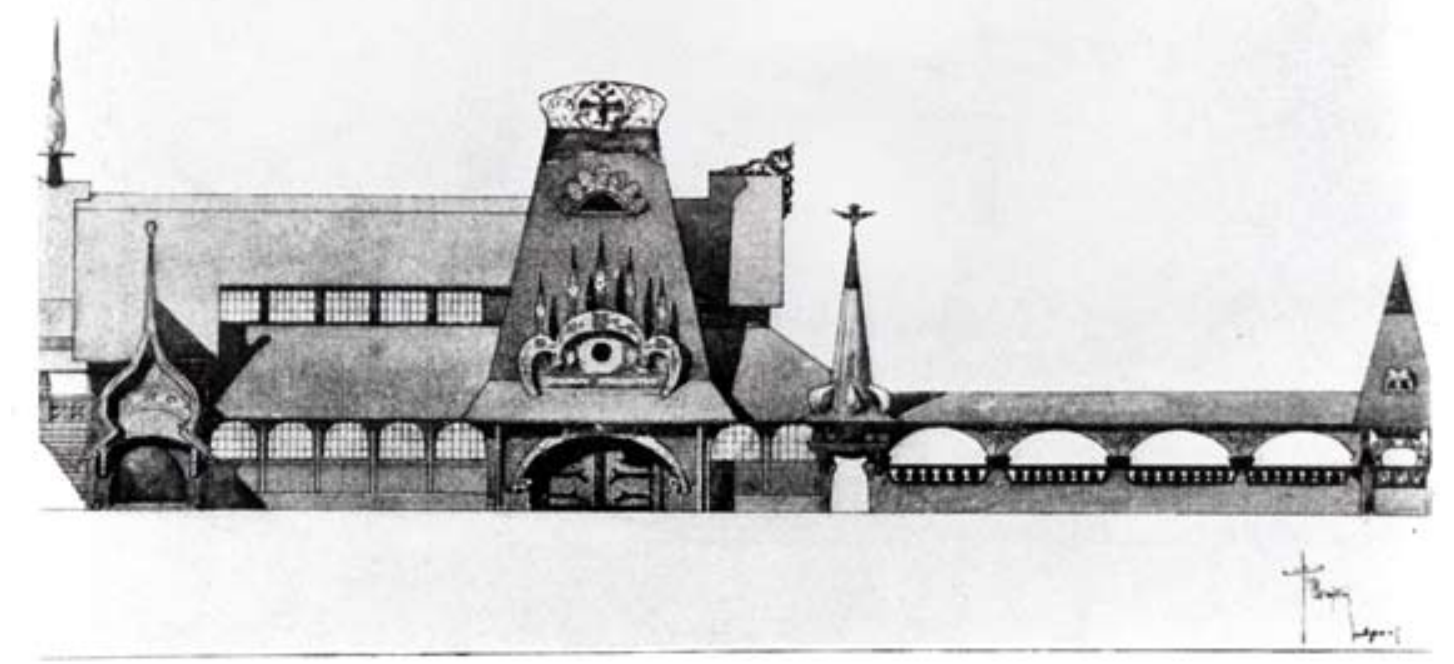

Fig. 27. Glasgow. Agricultural Pavilion, Russian section, 1901 Glasgow Exhibition. From Ezhegodnik Moskovskogo arkhitekturnogo obshchestva, 1909

with its exaggerated contours and asymmetry, the building itself seems to have germinated (Fig. 27). The bulges and spires (which mask a conservative rectangular floor plan) can also be traced to some of the more inventive examples of wooden architecture in the far north: the roof tower over the central entrance of the side facade was decorated with a burst of arched forms and capped by a metallic «coxcomb,» or crown, enclosing a large double-headed eagle in fretwork.

References to Russian traditional architecture on the smaller mining pavilion included the octagonal corner tower, reminiscent of the semidetached bell towers of large wooden churches. The entrance porch veered toward parody with its enormous horseshoe- and barrel-shaped arches. Of all the pavilions, this one was closest in style to art nouveau. In contrast, the massive forestry pavilion incorporated ornament with greater restraint. Apart from an entrance tower with a pyramidal roof and a few decorative bochka (barrel) gables, the exterior form of the building followed the interior plan. For the large panel that identified the pavilion Shekhtel designed a painted border of conifers and three gargantuan mushrooms, symbolizing the wealth of Russia's forests.

Indeed, all the pavilions displayed vivid polychrome in their carved and molded details and their facades. According to contemporary accounts, the agricultural pavilion was painted «pale green and salmon,» with red shingles, and the central pavilion was painted salmon, with brown shingles. Three pavilions had plank siding; the forestry pavilion, however, was constructed of notched, unplaned logs assembled in the timehonored Russian fashion by the peasant carpenters. This log pavilion (painted light brown) gave exhibit visitors a firsthand look at the ingenuity and artistry of Russian wooden architecture.

The mining and agricultural pavilions used minerals and plant forms for decorative effects 
more modestly than the forestry pavilion used its logs, though these other pavilions had caps of brilliant sheet metal (gilded zinc, aluminum) on their towers and on many of their pitched roofs. The entire project took seven months to complete and required four supervisory visits from Shekhtel ${ }^{15}$. Although the critical notices were mixed and the critics occasionally uninformed about the architect's identity, Shekhtel's work did not go unrecognized: the Royal Institute of British Architects made him an honorary member, and in Russia he attained the rank of Academician of Architecture ${ }^{16}$.

Shekhtel's final church, built in 1914 in the Moscow suburb Petrovsko-Razumovskoe, is his most sensitive and faithful re-creation of a traditional wooden architectural form ${ }^{17}$. Dedicated to St. Nicholas the Miracle Worker, the church (destroyed in 1918, but now rebuilt) is his purest expression of the appeal of northern Russian $\operatorname{architecture}^{18}$. Shekhtel's ingenuity in wooden construction for the Glasgow pavilions has been noted above. The church, understandably, does not have the decorative profusion of the pavilions, but the adherence to the forms of the traditional wooden church is rigorous $-\mathrm{a}$ tent-roofed octagonal tower over a square.

In fact the shape of the building, with its plank siding, placed a modern emphasis on fluid contours, from the central tower to the large extensions (each with its own roof) on the north, south, and west (Fig. 28). Here again one is reminded of Plotnikov's photograph of the Varzuga church, which revealed similar characteristics. The spatial unity of interior and exterior in the Shekhtel's church design was complemented by the iconostasis and furnishings, which the great architect also designed. Like Viktor Vasnetsov at Abramtsevo three decades earlier, Shekhtel found in the church the ideal way to integrate structure and the decorative arts.

Excellent prerevolutionary photographs of the building show an exquisite interior,

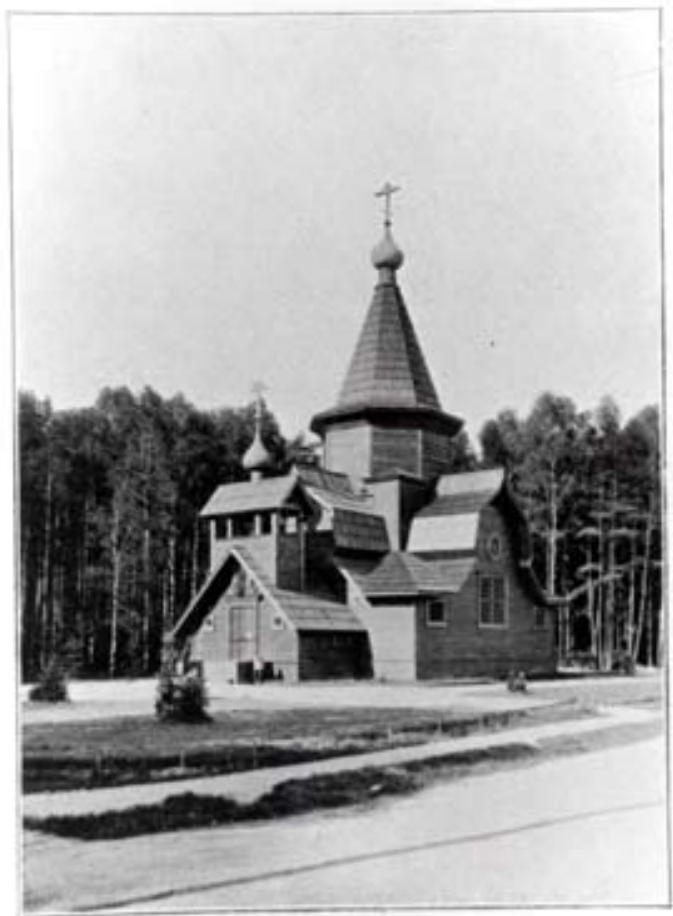

Fig. 28. Moscow. Church of the Tula Druzhina [Church of St. Nicholas] at Petrovskoe-Razumovskoe. From Ezhegodnik Moskovskogo arkhitekturnogo obshchestva, 1914-1916

contrasting the elaborate carving of the iconostasis with the pattern of unpainted knotty pine for the walls. Shekhtel stated his fondness for this project in messages on photographic postcards showing the church. To one of his nephews he wrote: «If you should by chance meet a devotee of the Russian northern style, give him this, my favorite little church, which worked so well for an atheist such as myself.» His postcard to the architect and designer Ivan Mashkov said simply: «In my opinion this is the best of my buildings"19. Although the structure has been recreated, there is a certain fateful logic in the fact that only photographs show us Shekhtel's original design. As in the work of Bilibin, Plotnikov and other photographerartists of the Russian north, photography has proven to be the primary medium for perpetuating the legacy of Russia's wooden architecture. 
On the Pogodin house, see William C. Brumfield, The Origins of Modernism in Russian Architecture (Berkeley: University of California Press, 1993), p. 7.

2 A description of the Porokhovshchikov house was published in D. Liushin, «Dereviannyi dom g-na Porokhovshchikova,» Zodchii, 1872, No. 2, p. 16. This volume also contains a plan and architectural drawings of the structure.

3 For a commentary on Mamontov's transformation of Abramtsevo, see G. Iu. Sternin, «Abramtsevo: ot 'usad'by' k 'dacha',» in the same author's Russkaia khudozhestvennaia kul'tura vtoroi poloviny XIX-nachala XX veka_(Moscow, 1984), pp. 18788. See also E. R. Arenzon, «Ot Kireeva do Abramtseva. K biografii Savvy Ivanovicha Mamontova,» Panorama iskusstv, 6 (1986), 359-82.

4 Elena Borisova, Russkaia arkhitektura vtoroi poloviny XIX veka (Moscow, 1979), p. 264.

5 Maliutin is the subject of a brief but informative article by Sergei Diagilev: «Neskol'ko slov o S. V. Maliutine,» in Mir Iskusstva, 1903, No. 4, pp. 157-60. The article is accompanied by a series of photographs of Maliutin's work, primarily at Talashkino.

6 G. Iu. Sternin, Russkaia khudozhestvennaia kul'tura vtoroi poloviny XIX-nachala XX veka (Moscow, 1984), p. 179.

A series of photographs of Maliutin's design for the apartment interior appeared in Ezhegodnik Obshchestva ArkhitektorovKhudozhnikov, No. 3 (1908), pp. 79-83. See also William Brumfield, «The Decorative Arts in Russian Architecture: 19001907,» The Journal of Decorative and Propaganda Arts, No. 5 (1987), pp. 12-27.

8 «Neskol'ko myslei o sovremennom prikladnom iskusstve v Rossii,» Mir iskusstva, 1902, No. 3, pp. 51-56. It is revealing that Grabar's solution for a revival of furniture design in Russia stems not from modernized folk art, but from a revival of Russia's Empire furniture designs of the turn of the nineteenth century - thus anticipating the revival of neoclassicism in both architecture and interior design later in the decade.

9 «Narodnoe tvorchestvo severa,» Mir iskusstva, 1904, No. 11, pp. 303-318.

10 On the development of Russian photography, see S. Morozov, Russkaia khudozestvennaia fotografiia. Ocherki iz istorii fotografii 1839-1917 (Moscow: Iskusstvo, 1955); and E. V. Barchatova, et al., A Portrait of Tsarist Russia: Unknown Photographs from the Soviet Archives (New York: Pantheon, 1989). The importance of photography in major St. Petersburg collections is demonstrated by a volume compiled by the art critic Vladimir V. Stasov: Fotograficheskie I fototipicheskie kollektsii imperatorskoi publichnoi biblioteki (St. Petersburg, 1885). On the work of Prokudin-Gorskii and its collection in the Library of Congress, see William C. Brumfield, «The Color Photographs of Sergei Mikhailovich Prokudin-Gorskii,» Visual Resources, 6(1990):243-255. For another approach to color photography at the same period, see Richard Davies, ed., Leonid Andreyev. Photographs by a Russian Writer (London: Thames and Hudson, 1989).

11 Igor' Grabar', Istoriia russkago iskusstva, vol. 1 (Moscow: I. Knebel, 1910).

12 On the Dormition Church at Varzuga, see I. A. Bartenev and B. N. Fedorov, Arkhitekturnye pamiatniki russkogo severa (Leningrad-Moscow: Iskusstvo, 1968), pp. 96-97; and A. V. Opolovnikov, Russkii Sever (Moscow: Stroiizdat, 1977), pp. $136,138$.

13 For a detailed account of the Glasgow pavilions, see Catherine Cooke, «Shekhtel in Kelvingrove and Mackintosh on the Petrovka,» Scottish Slavonic Review, No. 10 (1988), pp. 177-205.

14 This information is given in Zodchii, 1902, No. 1, p. 14.

15 Ibid.

16 Kirichenko, Fedor Shekhtel, p. 49.

17 Between 1910 and 1917 Shekhtel designed four churches, of which three were built. A description of Shekhtel's church at Balakovo appeared in Zodchii, 1911, No. 51, p. 541; and project sketch, plate 60. For a detailed analysis of medieval tower churches in Russia, see M. A. Ilin, Russkoe shatrovoe zodchestvo. Pamiatniki serediny XVI veka (Moscow, 1980).

18 The church is listed in M. Aleksandrovskii, Ukazatel moskovskikh tserkvei (Moscow, 1919), p. 52. According to Aleksandrovskii the church was consecrated on July 20, 1916. In a caption to a photograph in the 1914-16 issue of Ezhegodnik MAO, it is identified as the Church of the Tula Druzhina - presumably referring to the patriotic organization that sponsored the construction. The church is also frequently identified by its location near Solomennaia Storozhka. It has recently been rebuilt.

19 Quoted in Kirichenko, Fedor Shekhtel, p. 125, with reference to archival material in TsGALI.

\title{
Стиль модерн и открытие деревянной архитектуры Русского Севера: роль фотографии
}

\author{
У.К. Брумфильд \\ Университет Тулейн \\ Новый Орлеан, Луизиана, США
}

В девятнадиатом веке повышенный интерес вызывает «отсталость» деревянного зодчества допетровской России, когда российские интеллектуаль и художники начинают поиски истоков, прообразов и аутентичности в родной культуре. Широко распространяются и публи- 
куются гравюры традициионых конструкций. Среди первых художников, которые распознали в деревянном просторечии стилистическое вдохновение, были Виктор Гартман и Иван Ропет, оба они работали в Абрамцево в начале 1870-х г2. Другие художники Абрамцево-Василий Поленов, Виктор Васнецьо, Константин Коровин и в некоторой степени Александр Головинпредставили свою живописную концепцию массы и пространства в архитектоничной форме. Возрождение ремесел и использование народных мотивов демонстрируют слияние целей и понимания между художниками, декораторами и архитекторами на рубеже веков. Логическая связь между материалом и структурой в средневековых или народных традициях допетровской русской архитектуры была эстетически истолкована в неорусском варианте стиля модерн, который распространился в начале двадцатого века по всей России. В этой области особое значение имеет работа Сергея Малютина. В статье рассматривается решающая роль, которую сыграла фотография на рубеже веков в представлении форм традиционной деревянной архитектуры российской общественности и самого архитектора. Особое значение имело издание многотомной истории русского искусства Игоря Грабаря, первая часть которой была посвящена допетровской архитектуре, в том числе деревянным церквям Севера, запечатленным на фотографиях такого художника, как Иван Билибин. Статья завершается обсуждением работы Федора Шехтеля в контексте фотографий традиционной деревянной архитектуры.

Ключевые слова: деревянное зодчество, Абрамцево, Виктор Гартман, Иван Ропет (Петров), Василий Поленов, Виктор Васнецьов, Константин Коровин, Сергей Малютин, Талашкино, стиль модерн, неорусский стиль, Сергей Дягилев, Игорь Грабарь, Иван Билибин, Федор Шехтель, международные выставки.

Научная специиальность: 17.00.00-искусствоведение. 